\title{
First record of the freshwater copepod Eucyclops titicacae Kiefer, 1957, new rank (Copepoda, Cyclopoida) in Colombia
}

\author{
Juan Manuel Fuentes-Reinés ${ }^{1,3}$ \& Eduardo Suárez-Morales ${ }^{2}$ \\ ${ }^{1}$ Universidad del Magdalena, Grupo de Investigación en Limnología. \\ A.A 731 Santa Marta, Magdalena, Colombia \\ ${ }^{2}$ El Colegio de la Frontera Sur (ECOSUR), A.P. 424, 77014 Chetumal, Quintana Roo, Mexico \\ ${ }^{3}$ Corresponding author: Juan Manuel Fuentes-Reinés, e-mail: juanmanuelfuentesreines@yahoo.com
}

FUENTES-REINÉS, J. M. \& SUÁREZ-MORALES, E. First record of the freshwater copepod Eucyclops titicacae Kiefer, 1957, new rank (Copepoda, Cyclopoida) in Colombia. Biota Neotrop. (13)4: http://www. biotaneotropica.org.br/v13n4/en/abstract?article+bn01613042013

\begin{abstract}
The freshwater cyclopoid copepod Eucyclops titicacae Kiefer, 1957, new rank, was previously known as a subspecies of E. neumani (Pesta, 1927). Hitherto, it was recorded only from Lake Titicaca in Peru and Lake Valencia in Venezuela. This species is here recorded from Laguna Navío Quebrado, La Guajira, northern Colombia. This is the first record of E. titicacae in Colombia and the third locality in which this species has been reported from. We provide comparative data on the morphology of this copepod. The Colombian specimens have the combination of diagnostic features of E. neumani titicacae as reported in both the original description and subsequent taxonomical accounts, including: 1) spinules on caudal rami not reaching halfway the outer margin; 2) caudal rami length/width ratio $=6.0 ; 3$ ) length/width ratio of third endopodal segment of fourth leg=1.66;4) inner spine of fifth leg being shorter than the two adjacent setae. The consistent morphologic differences and the isolation of E. neumani titicacae with respect to E. neumani neumani, each related to a different biogeographic subregion in South America, support the notion that these are two separate species, E. neumani and E. titicacae. Considering this interesting addition, the number of species of Eucyclops known from Colombia increases to 8; a key for the identification of these species is also provided.

Keywords: continental copepods, taxonomy, freshwater zooplankton, Laguna Navio Quebrado, Colombia, distribution.
\end{abstract}

FUENTES-REINÉS, J. M. \& SUÁREZ-MORALES, E. Primer registro del copépodo de agua dulce Eucyclops titicacae Kiefer, 1957, nuevo rango (Copepoda, Cyclopoida) en Colombia. Biota Neotrop. 13(4): http://www. biotaneotropica.org.br/v13n4/pt/abstract?article+bn01613042013

Resumen: El copépodo ciclopoide de agua dulce Eucyclops titicacae Kiefer, 1957, nuevo rango, se conocía previamente como una subespecie de E. neumani (Pesta, 1927). Se había registrado solamente en los lagos Titicaca en Perú y Valencia en Venezuela. Esta especie se registra ahora en la Laguna Navío Quebrado, La Guajira, norte de Colombia. Este es el primer reporte de E. titicacae en Colombia y la tercera localidad en cual esta especie ha sido reportada. Se ofrece información comparativa sobre la morfología de este copépodo. Los especímenes de Colombia tiene la combinación de caracteres diagnósticos de E. neumani titicacae como se presentaron en la descripción original y en trabajos taxonómicos subsecuentes, incluyendo: 1) las espínulas de la rama caudal no alcanzan la mitad del margen externo, 2) la relación largo/ancho de la rama caudal $=6.0,3$ ) la relación longitud/ ancho del tercer segmento endopodal de la cuarta pata $=1.66,4)$ la espina interna de la quinta pata es más corta que las dos setas adyacentes. Las consistentes diferencias morfológicas y el aislamiento de E. neumani titicacae con respecto aE. neumani neumani, que se distribuyen en subregiones biogeográficas distintas en América del Sur, apoyan la idea de que se tratan de dos especies separadas, E. neumani y E. titicacae. Considerando esta interesante adición, el número de especies deEucyclops conocidas para Colombia se incrementa a 8; se proporciona una clave para la identificación de estas especies.

Palabras clave: copépodos continentales, taxonomía, zooplancton de agua dulce, Laguna Navío Quebrado, Colombia, distribución. 


\section{Introduction}

The freshwater cyclopoid copepod Eucyclops neumani (Pesta, 1927), described originally from Argentina, is known to contain two subspecies, E. neumani neumani (Pesta, 1927), distributed mainly in Argentina, Paraguay and Brazil (Reid 1985, Dussart \& Frutos 1986, Silva 2008, Mercado-Salas et al. 2012) and E. neumani titicacae Kiefer 1957, originally described from Lake Titicaca (Peru and Bolivia) (Kiefer 1957). According to Alekseev \& Defaye (2011), E. neumani titicacae is a member of the E. serrulatus species group, comprising species with 12-segmented antennules bearing a smooth hyaline membrane on the three distal segments, caudal ramus of moderate length (3.5-7.0 length/width ratio), a strong inner spine of leg 5, and one or two groups of hairs on the distal margin of the antennary basipodite, among other characters.

As stated by Silva (2008), E. neumani titicacae was previously known to be restricted to its type locality, Lake Titicaca, where it has also been recorded as E. neumani (Ueno 1966). However, it was realized that an older record of "Cyclops serrulatus" published by Pearse (1922) from Lake Valencia, Venezuela, was assignable to E. neumani titicacae (Reid 1985). It was subsequently reported, also as E. neumani by Infante (1978) and Infante et al. (1979) from the same Venezuelan lake (Reid 1985). These two large Neotropical lakes (Titicaca and Valencia) are the only sites in which this subspecies has been observed. During a biological survey of the lagoon system in the La Guajira region in northern Colombia, littoral plankton samples were obtained. Female specimens of a cyclopoid copepod assignable to E. neumani titicacae were collected. We report this finding together with a morphological comparison with $E$. n. neumani to support this interesting record in Colombia.

\section{Material and Methods}

A limnological survey of the Laguna Navío Quebrado (11 $25^{\prime} \mathrm{N}$, $\left.75^{\circ} 5^{\prime} \mathrm{W}\right)$, in the department of La Guajira, northern Colombia was carried out during the dry season (April, 2012). A total of three adult female specimens of Eucyclops neumani titicacae were found in a sample taken with a plankton net $(0.4 \mathrm{~mm}$ mesh size $)$ hauled among submerged macrophytes at a depth of $0.5 \mathrm{~m}$. The $\mathrm{pH}$ of the water was 7.6. The original samples were fixed and preserved in $70 \%$ ethanol. The specimen was dissected and the taxonomically relevant appendages were mounted in semi-permanent slides that were deposited in the Museo de Colecciones Biológicas of the Universidad Del Atlántico, Barranquilla-Atlántico, Colombia (UARC). The appendages were photographed using a Kodak Easy Share C140 digital camera adapted to a compound microscope; drawings were prepared with a camera lucida. The specimens were deposited in the collection of the Museum of the Universidad del Atlántico, in Barranquilla, Colombia (UARC) and in the first author's collection. The identification key presented in this contribution was prepared following the species discriminating characters proposed by Reid (1985) and Suárez-Morales et al. (2004).

\section{Results and Discussion}

Order Cyclopoida BURMEISTER, 1835

Family Cyclopidae RAFINESQUE, 1815

Subfamily Eucyclopinae KIEFER, 1927

Genus Eucyclops Claus, 1893

Eucyclops titicacae Kiefer, 1957, new rank

Material examined: Three adult female specimens collected April, 2012 from Laguna Navío Quebrado ( $\left.11^{\circ} 25^{\prime} \mathrm{N}, 75^{\circ} 5^{\prime} \mathrm{W}\right)$, altitude: $0 \mathrm{~m}$, La Guajira, northern Colombia, plankton net of $45 \mu \mathrm{m}$ mesh size, among submerged macrophytes. Specimens dissected, semi-permanent slides (UARC88M-95M).

Morphology. Body length of female specimens: 0.98-1.03 mm (Figure 1A). Our specimens are slightly smaller than those from Lake Titicaca and Lake Valencia (females 1.0-1.27 mm). Body shape and proportions as described by Kiefer (1957). The specimen examined bears the diagnostic features of E. neumani titicacae, as follows:

Antennules with 12 segments (Figure 1B), armature per segment as follows ( $\mathrm{s}=\mathrm{seta}, \mathrm{ae}=$ aesthetasc, $\mathrm{sp}=$ spine): $1(8 \mathrm{~s}), 2(4 \mathrm{~s})$, $3(2 s), 4(6 s), 5(4 s), 6(1 s+1 s p), 7(2 s), 8(3 s), 9(2 s+1 a e), 10(2 s)$, $11(3 \mathrm{~s}), 12(8 \mathrm{~s})$. The proportional length of the last three antennulary segments are, from proximal to distal: 24.2: 35.7: 40.1 (Figure 1C), similar to the proportions of the original description (25.8: 33.6: 40.6) (Kiefer 1957, fig. 12). The three distal segments (10-12) have a smooth hyaline membrane that is typical among members of the E. serrulatus-species group (Alekseev \& Defaye 2011) (Figure 1C, D). The ornamentation of the antennal basis was not fully observable in the specimen available and is thus incomplete, but some of the main groups of spines were identified (Figure 1F); in general, their position and number of elements agrees with the data provided by Alekseev \& Defaye (2011) for E. neumani titicacae. The first swimming leg has 3-segmented endopod and exopod, the inner basipodal seta is strong, setulose and with spinules at its point of insertion (Figure 2A). The intercoxal sclerite has a medial row of small spinules (arrowed in Figure 2B). The second leg (Figure 2C) has also 3-segmented rami and the intercoxal sclerite has a single medial row of spinules (arrowed in Figure 1E). The third leg (Figure 3A) has 3 -segmented rami and the intercoxal sclerite has two rows of spinules (II and III, following Alekseev \& Defaye 2011) on medial position (Figures 2E,F, 3B). The absence of distal row I is a difference of the Colombian specimens with respect to the type locality; in those specimens Alekseev \& Defaye (2011) reported the presence of row I with long hair-like elements. The fourth leg has also 3-segmented rami (Figure 3C), the third endopodal segment of leg 4 is about 1.66 longer that it is wide (Figure $3 \mathrm{C}$ ); the proportion of this structure measured from the original description is 1.57 (Kiefer 1957, fig. 13) and 1.55 from Ueno's report (Ueno 1966, fig. 71). The ornamentation of the intercoxal sclerite of the fourth swimming leg is represented by 3 rows of spinules (I-III) with longer elements along the distal margin (row I) (arrows in Figure 3D, Kiefer 1957, fig. 13). In addition, the inner basipodal seta is uniserially setulated in the Colombian specimen (Figures 3D, 4A), a character also present in the specimens from Lake Titicaca (Kiefer 1957, fig. 13). The ornamentation of the fourth leg coxopodite (Figure 4B, C) was evaluated following the nomenclature proposed by Alekseev \& Defaye (2011); groups A, B, $\mathrm{C}+\mathrm{D}, \mathrm{E}, \mathrm{H}$, and I are present, thus agreeing with Alekseev \& Defaye (2011) observations from the type specimens. The fifth leg inner spine is shorter than the two adjacent setae (Figures 4D, E, Kiefer 1957, fig. 14, Ueno 1966, fig. 70). In the Colombian specimen the spinules on the outer margin of the caudal rami are restricted to a row of 4-6 spinules inserted on a reduced area close to the insertion of the outer seta. The row of spinules does not reach half the length of outer margin (Figure 4F, Kiefer 1957, fig. 11, Ueno 1966, fig. 70). The length/width proportion of the caudal ramus in the Colombian specimen (6.0) (Figure 4F) is within the range known in the Titicaca specimens, varying between 5.7 and 6.4 (Kiefer 1957, Ueno 1966, Reid 1985). In our specimen the length ratio dorsal caudal seta/ caudal ramus length is 0.4 ; this ratio is 0.3 in the Titicaca specimens (Kiefer 1957).

This species closely resembles its congener E. neumani, also a Neotropical species (Pesta 1927, Reid 1985, Dussart \& Frutos $1986)$ and both can be easily confused. Ueno (1966) reported it as E. neumani from the Bolivian side of Lake Titicaca; it is probable 

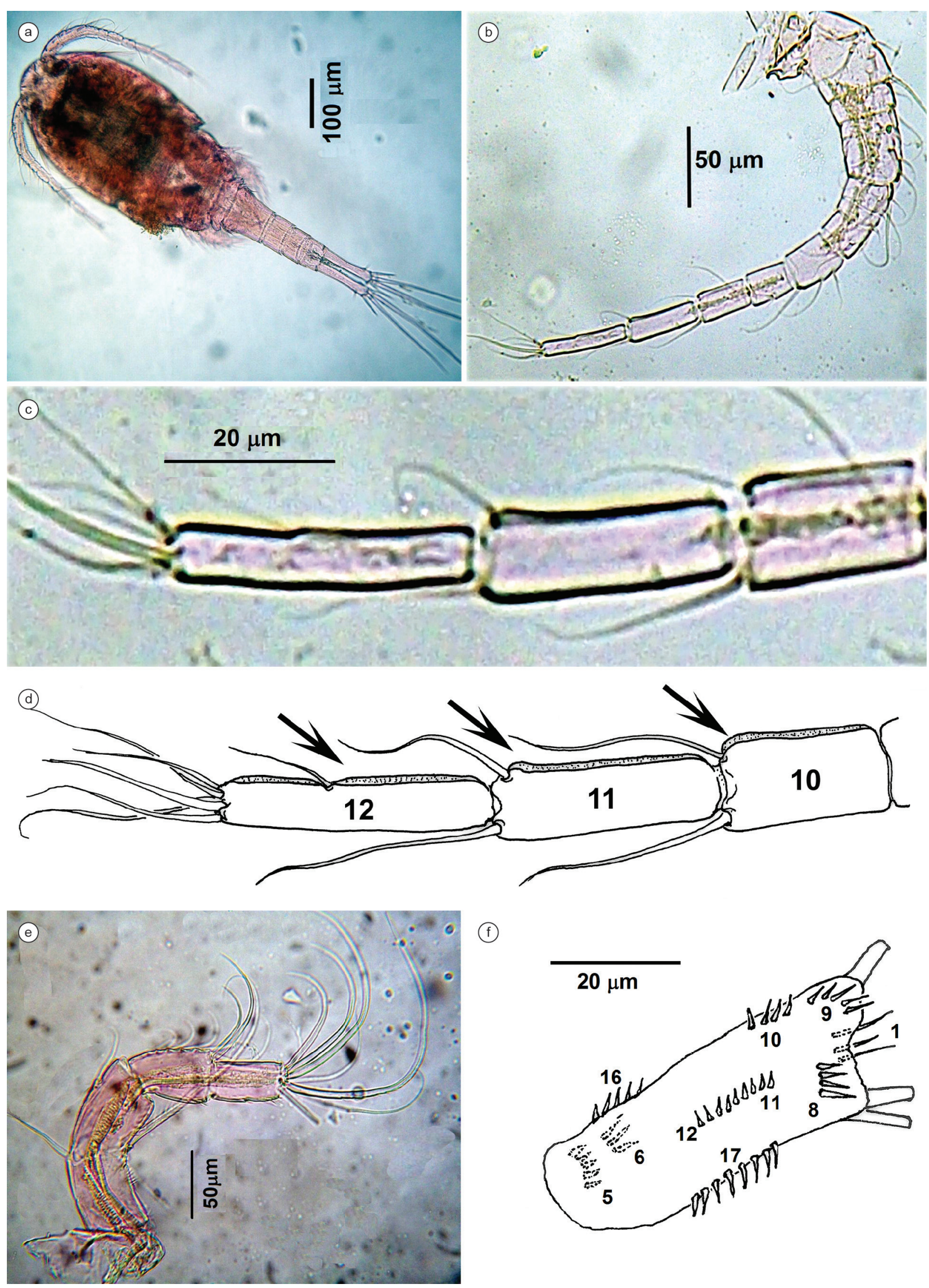

(f)

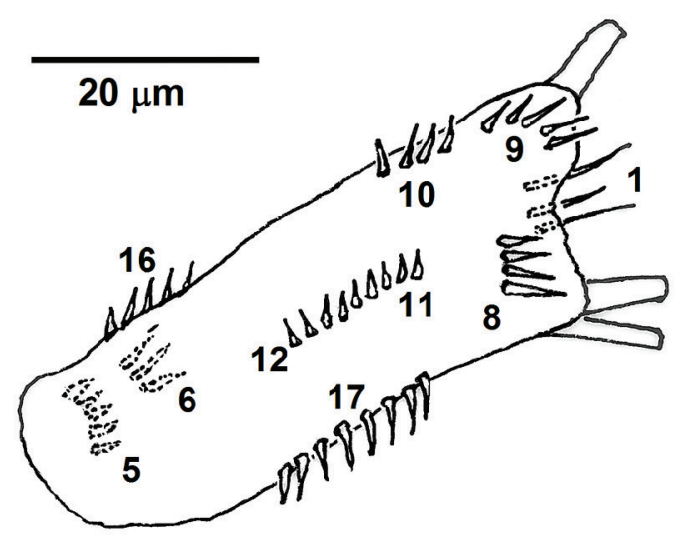

Figure 1. Eucyclops neumani titicacae from La Guajira, Colombia. Adult female. A. habitus, dorsal view. B. antennule. C. distal three antennulary segments. D. same, showing smooth hyaline membrane (arrowed) on segments 10-12; E. antenna; F. antennary ornamentation showing combined caudal and frontal surfaces; nomenclature of spine groups follows Alekseev \& Defaye (2011). 

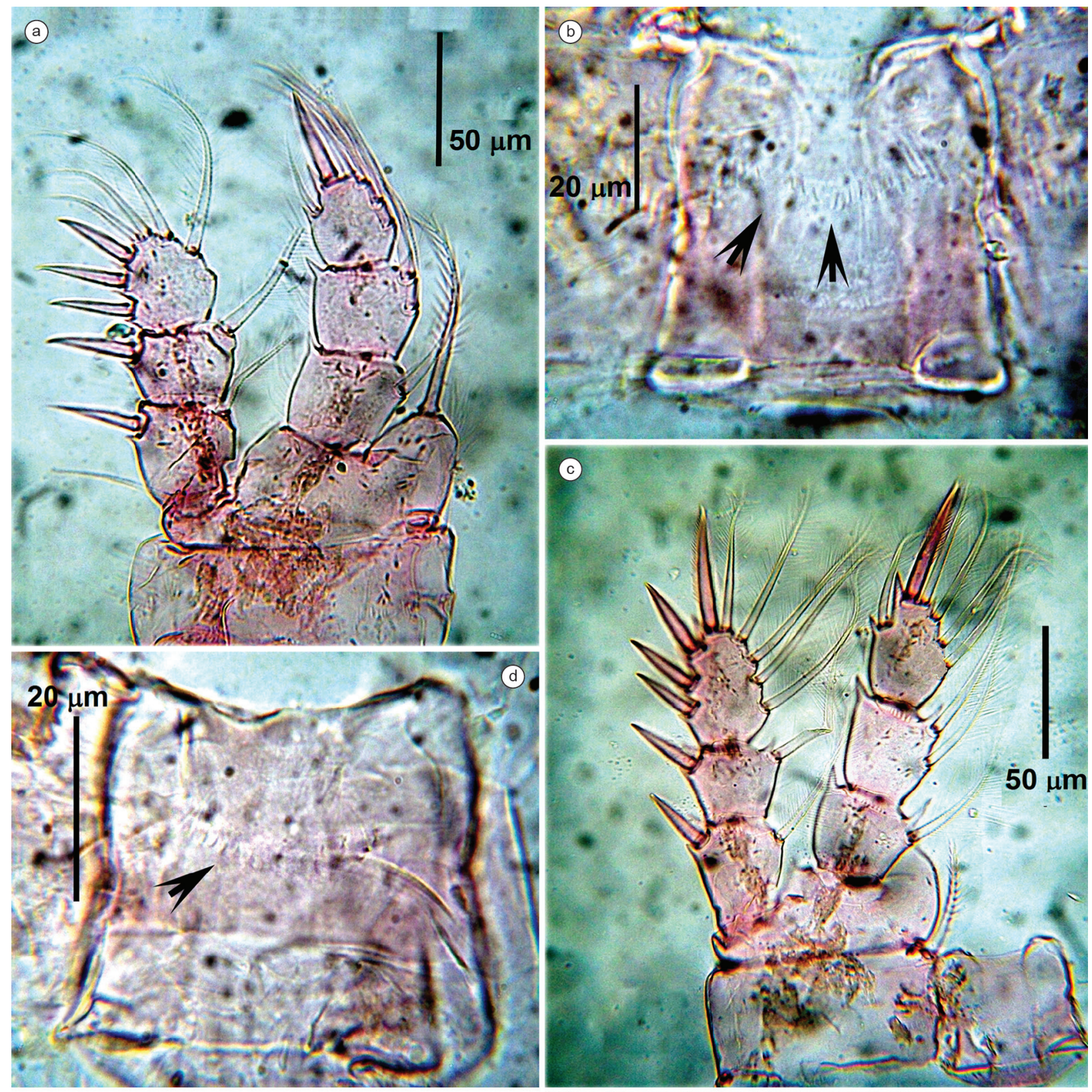

(e)
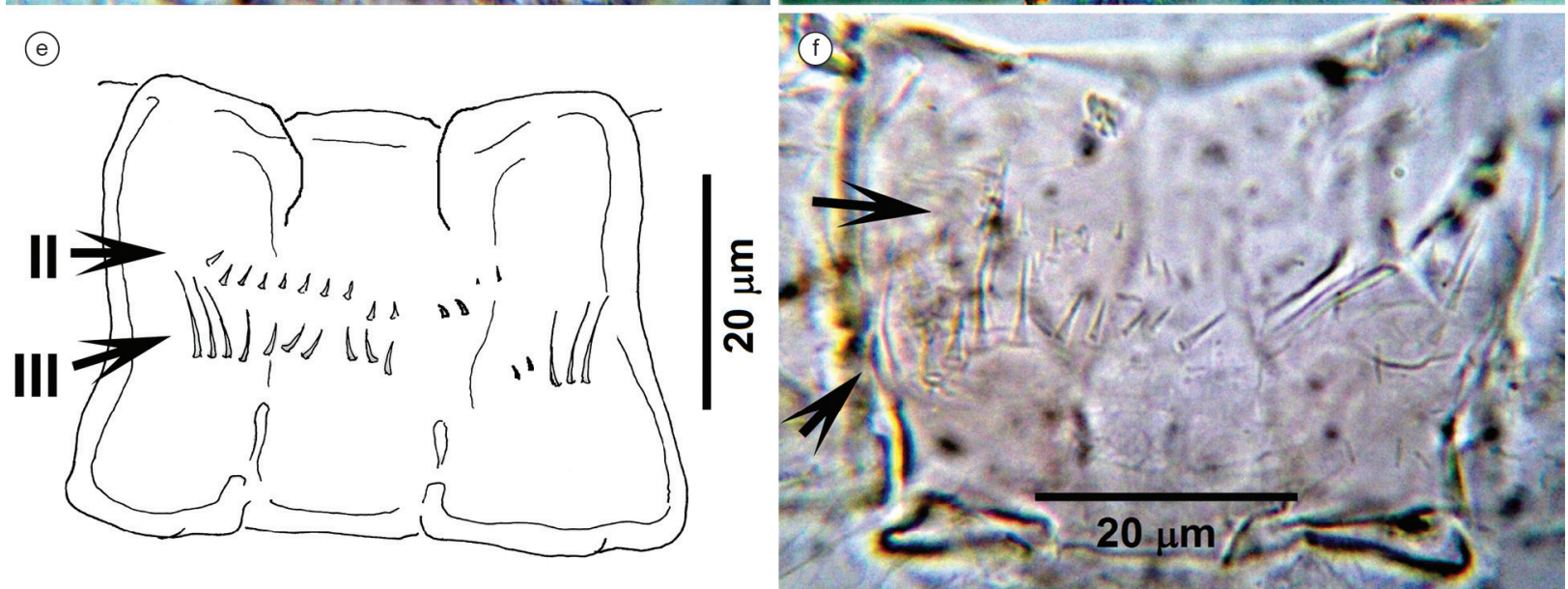

Figure 2. Eucyclops neumani titicacae from La Guajira, Colombia. Adult female. A. leg 1. B. intercoxal sclerite of leg 1. C. leg 2. D. intercoxal sclerite of leg 2. Intercoxal sclerite of leg 3 (E) showing two rows (II, III) of setal elements, nomenclature follows Alekseev \& Defaye (2011); F. same, with position of both rows (arrowed). 

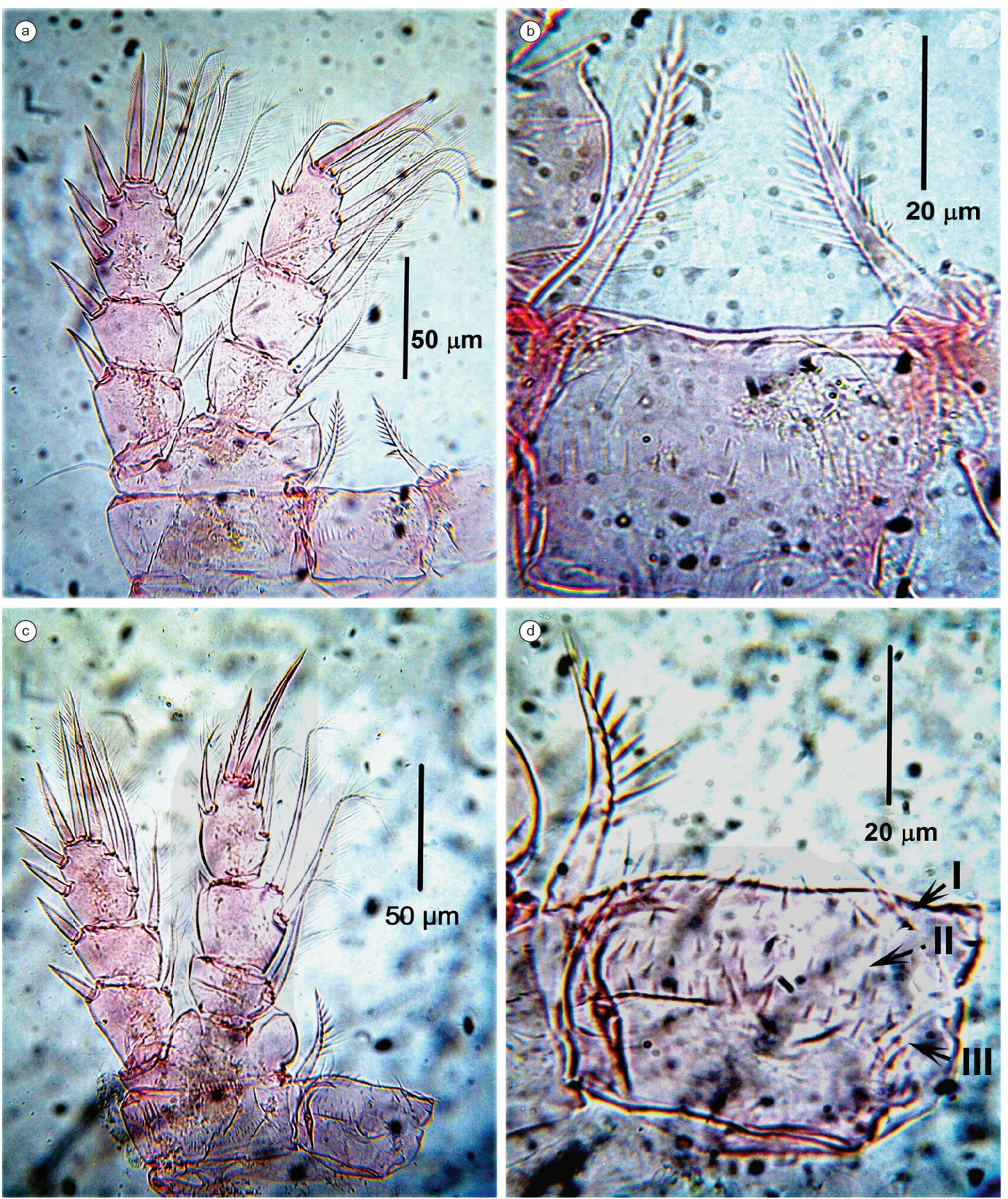

Figure 3. Eucyclops neumani titicacae from La Guajira, Colombia. Adult female. A. leg 3. B. intercoxal sclerite of leg 3; C. leg 4; D. intercoxal sclerite of leg 4 showing three rows (I-III) of setal elements, nomenclature follows Alekseev \& Defaye (2011).

that he was not aware of Kiefer's description of N. neumani titicacae. These two subspecies can be distinguished by several subtle characters including: 1 ) the consistently shorter saw of the caudal rami in E. n. titicacae, mainly restricted to a few spinules (4-6) adjacent to the insertion point of the outer lateral seta (Ueno 1966, fig. 70). In E. n. neumani the saw is clearly longer, with more spines $(+15)$, and it reaches half the length of the ramus (Reid 1985, Dussart \& Frutos 1986, fig. 33); 2) the length/width ratio of the third endopodal segment of the fourth leg is 1.5-1.6 in E. n. titicacae (Ueno, 1966, fig. 71) and 1.8 in E. n. neumani (Dussart \& Frutos 1986, fig. 35); 3) the length of the fifth leg spiniform setal element is shorter than the other two setae in E. n. titicacae (Kiefer 1957, Ueno 1966) whereas the three elements are equally long in E. n. neumani (Dussart \& Frutos 1986, fig. 34). An additional character is the length ratio of the dorsal seta/ caudal ramus length, the figure is 0.22 in E. n. neumani (Dussart \& Frutos 1986) and 0.30-0.45 in E. neumani titicacae. Overall, it is confirmed that the morphological differences between these two taxa are consistent and are probably related to separate species.

\section{Distribution}

According to the biogeographic analysis by Mercado-Salas et al. (2012), the track of E. n. titicacae runs from Lake Titicaca-Peru to Lake Valencia-Venezuela. The latter water body is relatively near the new locality in Colombia. Hence, this finding is consistent with the Western Amazonian (WA) biogeographic track defined for this subspecies (Mercado-Salas et al. 2012) and expands this track toward the northern Colombian coast. This WA track also connects two important Neotropical basins, the Amazon and the Orinoco; a recent survey provides evidence showing active gene flow and dispersal between these two large basins through the Casiquiare corridor (Willis et al. 2010). The southern limits of the large Amazonian subregion are determined by the historical separation of the Paraguay 

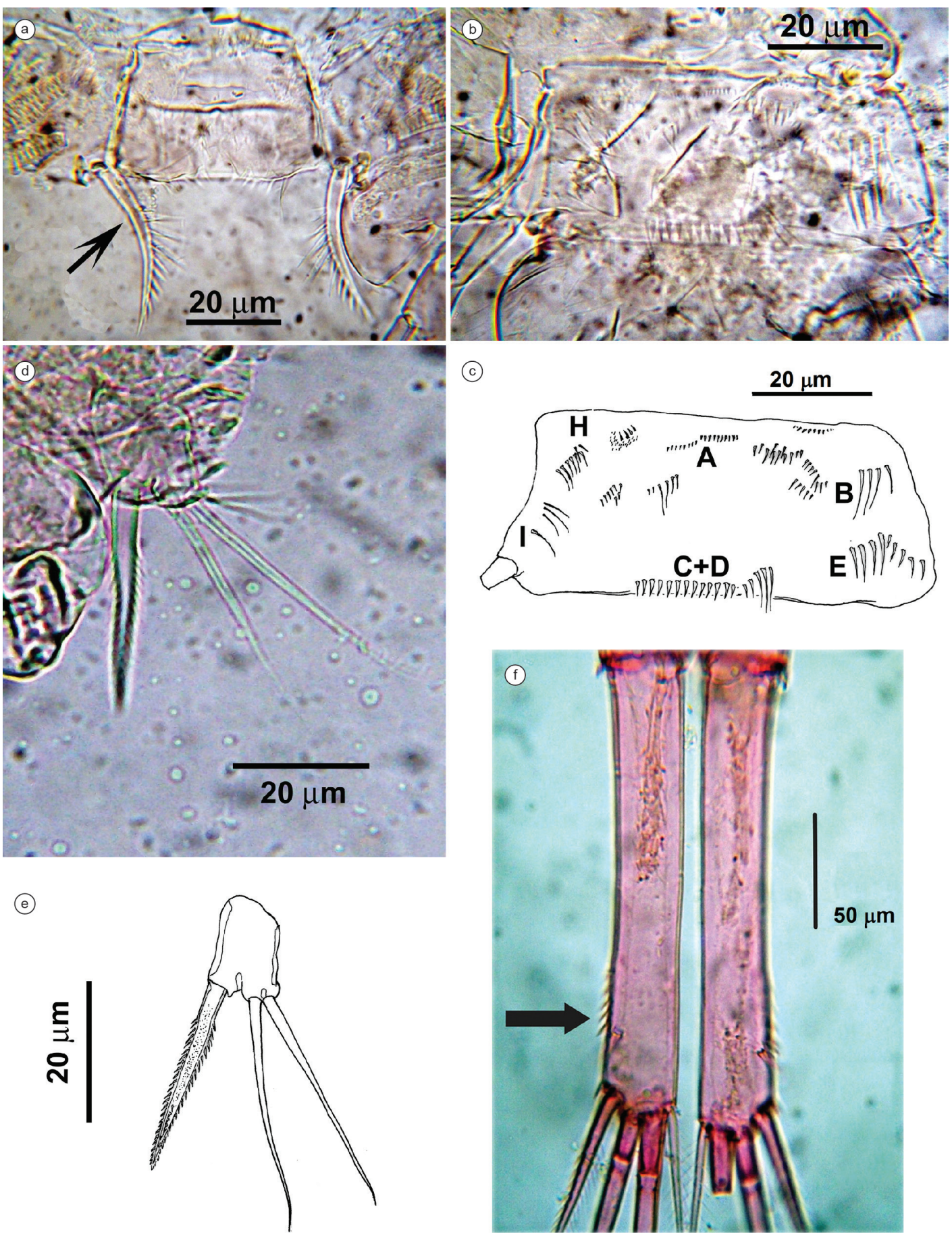

Figure 4. Eucyclops neumani titicacae from La Guajira, Colombia. Adult female. A. leg 4, intercoxal sclerite of another specimen showing ornamentation and gap of inner coxal seta (arrowed); B. coxopodite of leg 4; C. coxopodite of leg 4 showing ornamentation following nomenclature by Alekseev \& Defaye (2011); D. fifth leg; E. fifth leg of another specimen showing spiniform seta shorter than adjacent terminal setae; F. caudal rami showing reduced saw (arrowed, with only 4-6 elements) on outer margin.

and Paraná rivers from the Amazonas basin. This biogeographic province, the Chacoan subregion (Urtubey et al. 2010) is independent from that related to the known distributional pattern of E. n. neumani, a species known from Argentina, Paraguay, Uruguay, and central and southern Brazil (Reid 1985, Mercado-Salas et al. 2012). This is an additional evidence to support the notion that these subspecies are likely to represent independent species, E. neumani (Pesta, 1927), and E. titicacae Kiefer, 1957.
The present record expands the occurrence of the former subspecies E. neumani titicacae (as E. titicacae) to Colombia, and it is now known to occur in three sites of South America (Figure 5). In addition, these localities represent also a remarkable range of altitude for this species: $3805 \mathrm{~m}$ (Lake Titicaca), $407 \mathrm{~m}$ (Lake Valencia), and $0 \mathrm{~m}$ (Navío Quebrado Lagoon). Considering this new record, the number of species of Eucyclops known for the Colombian copepod fauna (Gaviria \& Aranguren 2007) increased to 8. 


\section{RECORDS OF Eucylops titicacae Kiefer, 1957}

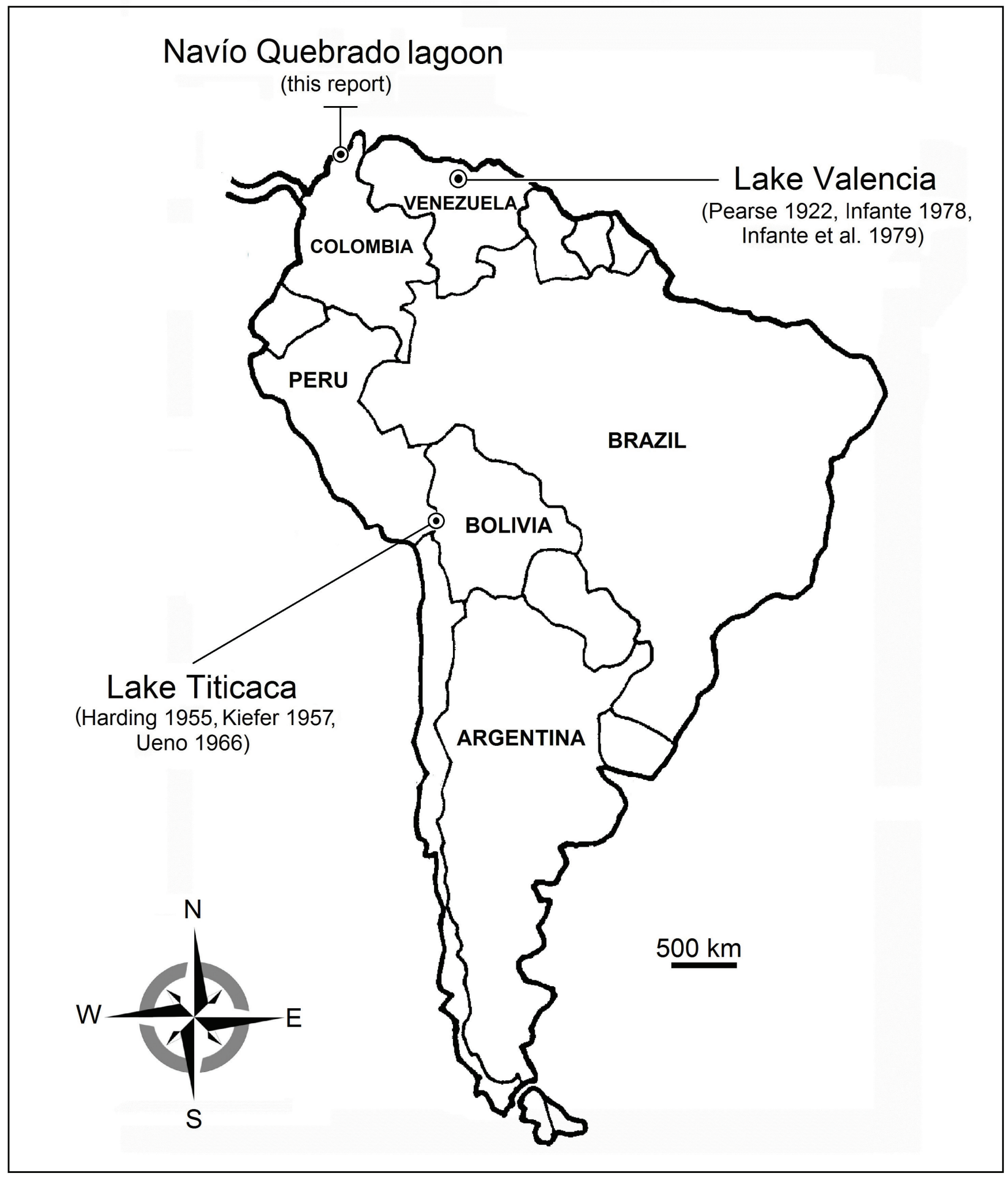

Figure 5. Map showing records of Eucyclops titicacae Kiefer, 1957, a species known from three localities in South America. 


\section{Key for the identification of the nominal species of Eucyclops recorded in Colombia}

Additional characters can be found in Reid (1985), Suárez-Morales (2004) and Alekseev et al. (2006).

1A. Caudal rami less than 5 times longer than wide.

1B. Caudal rami between 5.1-8.5 times longer than wide

2A. Serra of caudal rami extending about $1 / 8$ of outer margin, lateral caudal seta shorter than the ramus width

E. cf. alticola Kiefer, 1957

2B. Serra of caudal rami extending more than $1 / 8$ of outer margin, lateral caudal seta as long as or longer than ramus width...... 3

3A. Inner spine of leg 5 shorter than outer seta E. bondi Kiefer, 1934

3B. Inner spine of leg 5 about as long as outer seta......

4A. Middle seta of leg 5 as long as outer seta

E. pseudoensifer Dussart, 1984

4B. Middle seta of leg 5 clearly longer than inner seta

E. delachauxi (Kiefer, 1925)

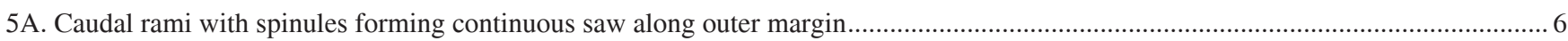

5B. Caudal rami saw with spinules arranged in one or two distinct groups along outer margin .......................................................... 7

6A. No setules on the caudal surface of the antennary basis. Setulation along the outer margin of the coxal spine of leg 4 with no gap......... .E. speratus (Lilljeborg, 1901)*

*Record probably assignable to E. solitarius, characters of this species should be checked. The distribution of $E$. speratus appears to be restricted to Europe (Alekseev et al. 2006)

6B. Caudal surface of the antennary basis with setules. Outer margin of coxal spine of leg 4 with gap ......... E. serrulatus (Fischer, 1851) ** ** This record from Colombia and others from South America should be revised as part of this complex species-group. The species is probably absent from South America (Alekseev \& Defaye 2011). For additional characters and updated taxonomic and morphological analyses of this species-group, see Alekseev et al. (2006) and the key provided by Alekseev \& Defaye (2011).

7A. Third endopodal segment of leg 4 about 1.6 times as long as wide, caudal rami saw short, represented by one group of a few spinules covering only the area close to insertion of lateral seta, saw not reaching half the length of outer margin.

E. titicacae Kiefer, 1957, new rank

7B. Third endopodal segment of leg 4 about 3 times as long as wide, caudal rami saw with two groups of spinules separated by a gap, spinules on proximal group shorter.

E. demacedoi Lindberg, 1957

\section{References}

ALEKSEEV, V. \& DEFAYE, D. 2011. Taxonomic differentiation and world geographical distribution of the Eucyclops serrulatus group (Copepoda, Cyclopidae, Eucyclopinae). In Studies on Fresh-water Copepoda: a Volume in Honour of Bernard Dussart (D. Defaye, E. Suárez-Morales \& C. Von Vaupel Klein, eds.). Crustaceana Monographs 16, E.J. Brill, Amsterdam, p.41-72.

ALEKSEEV, V.R., DUMONT, H.J., PENSAERT, J., BARIBWEGURE, D. \& VANFLETEREN, J.R. 2006. A redescription of Eucyclops serrulatus (Fischer, 1851) (Crustacea: Copepoda: Cyclopoida) and some related taxa, with a phylogeny of the E. serrulatus group. Zool. Scr. 35:123-147. http://dx.doi.org/10.1111/j.1463-6409.2006.00223.x

DUSSART, B.H. \& FRUTOS, S.M. 1986. Sur quelques Copépodes d'Argentine 2. Copépodes du Paraná Medio. Rev. Hydrobiol. Trop. 19(3d): $241-262$.

GAVIRIA, S. \& ARANGUREN, N. 2007. Especies de vida libre de la subclase Copepoda (Arthropoda, Crustacea) en aguas continentales de Colombia. Biota Colomb. 8:53-68.

HARDING, J.P. 1955. 15. Crustacea: Copepoda. The Percy Sladen Trust Expedition to Lake Titicaca in 1937. Trans. Linn. Soc. London, ser. 3, 1: $219-247$.

INFANTE, A. 1978. The zooplankton of Lake Valencia (Venezuela). I: Species composition and abundance. Verh. Internat. verein. Limnol. 20:11861191.

INFANTE, A., RIEHL, W. \& SAUNDERS, J.D. 1979. Los copépodos del Lago de Valencia, Venezuela. Acta Científ. Venez. 30:224-233.

KIEFER, F. 1957. Freilebende Ruderfüsskrebse (Crustacea Copepoda) des Titicaca sees. Veröff. Zool. Staatssamml. Muench. 4:125-150.
MERCADO-SALAS, N., POZO, C., MORRONE, J. \& SUÁREZ-MORALES, E. 2012. Distribution patterns of the American species of the freshwater genus Eucyclops (Copepoda: Cyclopoida). J. Crust. Biol. 32:457-464. http://dx.doi.org/10.1163/193724012X626502

PEARSE, A.S. 1922. Crustacea of Lake Valencia, Venezuela. Proc. U.S. Acad. Sci. 59:459-462.

PESTA, O. 1927. Ein Beitrag zur Kenntnis der Copepodenfauna von Argentinien. Zool. Anz. 73(3-4):67-80.

REID, J.W. 1985. Chave de identificação e lista de referencias para as espécies continentais sulamericanas de vida livre da ordem Cyclopoida (Crustacea, Copepoda). Bolm. Zool., Univ. São Paulo 9:17-143.

SILVA, W.M. 2008. Diversity and distribution of the free-living freshwater Cyclopoida (Copepoda: Crustacea) in the Neotropics. Braz. J. Biol. 68(4, Suppl.):1099-1106. PMid:19197479. http://dx.doi.org/10.1590/S151969842008000500016

SUÁREZ-MORALES, E. 2004. A new species of Eucyclops (Copepoda: Cyclopoida) from Southeast Mexico with a key for the identification of the species recorded in Mexico. Zootaxa 617:1-18.

UENO, M. 1966. Zooplankton of Lake Titicaca on the Bolivian side. Hydrobiologia 29:547-568. http://dx.doi.org/10.1007/BF00189910

URTUBEY, E., STUESSY, T.F., TREMETSBERGER, K. \& MORRONE, J.J. 2010. The South American biogeographic transition zone: an analysis from Asteraceae. Taxon 59:505-509.

WILLIS, S.C., NUNES, M., MONTAÑA, C., FARIAS, I.P., ORTIZ, G. \& LOVEJOY, N.R. 2010. The Casiquiare river acts as a corridor between the Amazonas and Orinoco river basins: biogeographic analysis of the genus Cichla. Mol. Ecol. 19:2014-1030. PMid:20149086. http://dx.doi. org/10.1111/j.1365-294X.2010.04540.x 